\title{
Mycoflora of Stone Fruit Mummies in California Orchards
}

\author{
C. X. Hong and T. J. Michailides, Department of Plant Pathology, University of California, Davis, Kearney Agri- \\ cultural Center, Parlier 93648; B. A. Holtz, University of California Cooperative Extension, Madera 93637
}

\begin{abstract}
Hong, C. X., Michailides, T. J., and Holtz, B. A. 2000. Mycoflora of stone fruit mummies in California orchards. Plant Dis. 84:417-422.

Stone fruit mummies infected by Monilinia fructicola were periodically collected in winter from trees and from the ground in eight orchards in 1995-96 and from five orchards in 1996-97. Mycoflora were determined by spreading mummy washings and plating inner tissues onto petri dishes containing acidified potato dextrose agar, then counting colonies of individual fungi after incubation at $23^{\circ} \mathrm{C}$ for 4 days. Twenty genera, representing 29 fungal species, were isolated from both mummy washings and inner tissues. Aspergillus japonicus, A. terreus, and species of Harknesia, Paecilomyces, and Trichoderma are the first recorded from species of Prunus in the United States, and Aureobasidium pullulans and Epicoccum purpurascens are the first reported for California. The principal mycoflora recovered from mummy washings were species of nonfilamentous yeasts (32.1\%), Penicillium (28.8\%), Cladosporium (11.4\%), and Mucor (10.8\%). Major mycoflora of mummy inner tissues were species of Penicillium (23.7\%), Mucor (19.6\%), Cladosporium (17.3\%), and Rhizopus (11.1\%). The relative recoveries of individual fungi from mummy inner tissues differed with location, Prunus species, and sampling position (tree or ground), and changed as the season progressed. The relative recovery of $M$. fructicola from mummy inner tissues was negatively correlated with Botrytis $(R=-0.53, P=0.0052)$, Penicillium $(R=-0.58, P=0.0681)$, and Rhizopus $(R=-0.50, P=0.0696)$. These results could help obtain naturally occurring antagonists and maximize their use in biocontrol systems aimed at reducing primary inoculum for blossom blight of stone fruits in California orchards.
\end{abstract}

Additional keywords: antagonism, carpo-stromasphere, nectarine, peach, plum, prune

Mummies of stone fruit (Prunus spp.) infected by Monilinia fructicola (G. Wint.) Honey can serve as a source of primary inoculum for initiating brown rot epidemics in California $(12,23)$ and other growing areas worldwide $(1,2,18)$. These mummies can either produce conidia (23) or develop apothecia, which release ascospores (12). The importance of mummies in the epidemiology of brown rot, however, varies among different geographic locations and between seasons within the same regions, as in California (15).

Two requirements must be met for mummies to function as a source of primary inoculum: (i) $M$. fructicola must survive the winter, and (ii) environmental conditions must be conducive for the fungus to sporulate during stone fruit bloom. In California, M. fructicola can survive some winters in mummy tissues $(13,23)$.

Corresponding authors: C. X. Hong and T. J. Michailides; E-mails: chhong2@vt.edu and themis@uckac.edu

Current address of C. X. Hong: Virginia Polytechnic Institute and State University, Hampton Roads AREC, 1444 Diamond Springs Road, Virginia Beach 23455.

Accepted for publication 10 December 1999.

Publication no. D-2000-0131-01R

(C) 2000 The American Phytopathological Society
Determining the factors that affect the survival of this fungus may help in understanding the epidemiology of brown rot and the development of disease management strategies.

Plant pathogens are vulnerable to antagonism from associated microflora during their saprophytic existence in plant residue. A minor change in the inhabitants of plant residues may have a great influence on the survival or activity of pathogens, but knowledge of the microflora inhabiting plant residue is scanty (4). During spring survey of stone fruit infected by $M$. fructicola, we frequently observed mummies overgrown with various fungi, which include species of Cladosporium, Penicillium, Trichothecium, or Trichoderma (14), from which we were unable to recover $M$. fructicola. The role that these colonizing fungi may play in relation to the survival of $M$. fructicola in mummies is unknown.

Research on plant microflora has increased tremendously in the last 20 years, and our knowledge of epiphytic $(9,19)$ and endophytic (29) microflora in the rhizosphere $(25,26)$ and phyllosphere has increased accordingly (3), but our knowledge of the microflora in the carpo-stromasphere is very limited. Knowledge of plant microflora has greatly facilitated naturally occurring biological control $(17,28)$ and the introduction of microorganisms for the biological control of plant pathogens (4).
For example, Penicillium frequentans and Epicoccum purpurascens were identified and developed as biological agents to control peach twig blight in Spain, following investigations on the mycoflora of peach twigs and flowers $(5,22)$. An isolate of Trichoderma atroviride was also identified in our laboratory for control of postharvest brown rot of stone fruits (16). In this research, we used stone fruit mummies as a model system and investigated the mycoflora in the carpo-stromasphere. The objective of this study was to determine mycoflora of mummies of nectarine, peach, plum, and prune infected by $M$. fructicola in California orchards.

\section{MATERIALS AND METHODS}

Sampling of mummies. Mummies infected by $M$. fructicola, with few if any visible contaminants on their surfaces, were collected from eight orchards at four locations in California monthly from November 1995 to March 1996. These orchards consisted of one peach ( $P$. persica), five nectarine ( $P$. persica var. nectarina), and two plum ( $P$. salicina). Mummies hanging from trees and lying on the ground were sampled separately and are referred to as tree mummies and ground mummies, respectively. Three replications of 30 tree mummies and 30 ground mummies were arbitrarily collected from each orchard, each placed separately in a clean plastic bag, kept in an ice box, and transported to the laboratory. During the winter of 199697, mummy sampling was repeated monthly in five orchards, including one peach, three nectarine, and one prune $(P$. domestica $\mathrm{cv}$. French), using the same procedure. Mummies were collected at the beginning of each month.

A total of 42 samples were taken from trees and 44 from the ground in the 199596 winter. During the winter of 1996-97, 25 samples of tree mummies and 25 samples of ground mummies were collected. The orchards sampled represented four major stone fruits growing in California: peach, nectarine, plum, and prune. These orchards were located in Fresno and Madera counties, in the center of the San Joaquin Valley, where most fresh market stone fruit are produced. The commercial orchards sampled were 8 to 10 years old, with late-season varieties, while the orchards at the Kearney Agricultural Center (KAC) were 18 to 22 years old, with middle-season varieties. Most orchards sampled received two to four bloom sprays and one to three preharvest sprays with either 
iprodione or benomyl (Table 1). The peach and plum orchards at the KAC were removed in the 1996-97 winter, so in their place we sampled a peach and a prune orchard in Madera County. The details of irrigation schedule and pesticide application were provided by growers.

Isolation from mummy washings. In 1995-96, five mummies per replicate were placed in a 500-ml clean plastic bottle containing $300 \mathrm{ml}$ of deionized water and shaken on an Eberbach shaker (Eberbach Corporation, Ann Arbor, MI) at 180 osc/min for $2 \mathrm{~h}$. According to preliminary studies, $100 \mu \mathrm{l}$ of the diluted mummy washings (1:100) was spread onto each of three petri dishes containing $20 \mathrm{ml}$ of acidified $(2.5 \mathrm{ml}$ of $25 \%$ lactic acid per liter) potato dextrose agar (APDA) using a turntable with a sterile L-shaped glass rod. Dishes were incubated at $23^{\circ} \mathrm{C}$ for 4 days, then examined microscopically for fungal colonies. A fungus that was frequently recovered from plant tissue was referred to as a colonizer of that tissue. A fungus was recorded as a major colonizer when it had $\geq 30$ colonies in a dish and as a minor colonizer when it had <30 colonies. The absolute predominance of a colonizer was represented by the number of dishes in which the species was recorded as a major colonizer. The absolute predominances of individual colonizers were added together to give a total predominance of all colonizers. For example, a dish with three major colonizers was counted as three predominant dishes in the total predominance. The relative predominance of individual colonizers was then calculated by dividing their predominance by the total predominance.
Isolation from mummy inner tissues. Five mummies were arbitrarily selected from each of three replicate bags. Each mummy was split with a flamed knife, and five small (approximately $2 \times 2 \times 2 \mathrm{~mm}$ ) pieces of the inner tissues were removed with a pair of fine forceps and placed at the center and across two perpendicular diameters of a dish containing $10 \mathrm{ml}$ of APDA. Dishes were incubated at $23^{\circ} \mathrm{C}$ for 4 days, then examined microscopically for fungal colonies. Using relevant taxonomic keys, fungal colonies were identified to species whenever possible. The number of colonies of each fungus per dish was recorded. Relative recovery was calculated by dividing the number of colonies of indi- vidual fungi by the total number of all fungal colonies recovered from mummies of each replicate and expressed as a percentage. Data of the relative recovery of individual fungi were examined for normality using the SAS UNIVARIATE procedure (SAS Institute, Cary, NC, 1999). Nonparametric analyses were subsequently performed using the SAS NPAR1WAY procedure for determining the differences in relative recovery of individual fungi between locations, species of stone fruits, sampling positions (tree versus ground), and using the SAS FREQ procedure for determining the difference among the sampling months. The data of mean relative recovery at different locations, species of

Table 2. Populations of colonizing fungi isolated from inner tissues and surface of stone fruit mummies in California orchards

\begin{tabular}{|c|c|c|c|}
\hline \multirow[b]{2}{*}{ Fungus } & \multicolumn{2}{|c|}{ Relative recovery $(\%)^{y}$} & \multirow{2}{*}{$\begin{array}{c}\text { Relative } \\
\text { predominance }(\%)^{\mathrm{z}} \\
1995-96\end{array}$} \\
\hline & $1995-96$ & 1996-97 & \\
\hline Alternaria & 2.0 & 0.4 & 0.2 \\
\hline Aspergillus & 1.9 & 8.8 & 2.4 \\
\hline Aureobasidium & 6.1 & 1.2 & 8.0 \\
\hline Botrytis & 8.0 & 1.5 & 0.2 \\
\hline Cladosporium & 17.3 & 6.4 & 11.4 \\
\hline Fusarium & 1.4 & 0.6 & 0.5 \\
\hline Gilbertella & 2.0 & 0.2 & 0.5 \\
\hline Monilinia & 1.5 & 13.5 & 0 \\
\hline Мисоr & 19.6 & 5.8 & 10.8 \\
\hline Penicillium & 23.7 & 32.7 & 28.8 \\
\hline Rhizopus & 11.1 & 8.0 & 4.7 \\
\hline Trichoderma & 1.4 & 3.5 & 0.0 \\
\hline Yeast & 2.0 & 14.6 & 32.1 \\
\hline Other fungi & 2.1 & 2.8 & 0.5 \\
\hline
\end{tabular}

y The relative recovery was calculated by dividing colony number of individual fungi by total colony number of all fungi recovered from inner tissue of mummies.

${ }^{\mathrm{z}}$ Relative predominance of a fungus recovered from mummy washing.

Table 1. Cultural practices and fungicides applied in stone fruit orchards sampled for mummies infected by Monilinia fructicola in 1995-96 and 1996-97 winters

\begin{tabular}{|c|c|c|c|c|c|c|c|c|}
\hline \multirow[b]{2}{*}{ Orchard } & \multirow[b]{2}{*}{ Site, county } & \multirow[b]{2}{*}{ Age (year) } & \multirow[b]{2}{*}{ First harvest } & \multirow[b]{2}{*}{ Irrigation $^{w}$} & \multirow[b]{2}{*}{ Herbicide $^{x}$} & \multicolumn{3}{|c|}{ Fungicide $^{y}$} \\
\hline & & & & & & $\mathbf{A}$ & B & C \\
\hline \multicolumn{9}{|l|}{$1995-96$} \\
\hline \multicolumn{9}{|l|}{ Nectarine } \\
\hline Fantasia & KAC, Fresno & 21 & $7 / 1$ & $7-14$ & B & 2 & 2 & 2 \\
\hline Summer Red & Parlier, Fresno & 8 & $8 / 15$ & $10-14$ & $\mathrm{C}$ & 2 & 2 & 2 \\
\hline August Red & Reedley, Fresno & 10 & $8 / 15$ & $10-14$ & $\mathrm{C}$ & $-^{\mathrm{z}}$ & - & - \\
\hline September Red & Reedley, Fresno & 10 & $9 / 1$ & $10-14$ & $\mathrm{C}$ & - & - & - \\
\hline Flaming Red & Madera, Madera & 9 & $8 / 20$ & 12 & $\mathrm{C}$ & 3 & 4 & 3 \\
\hline \multicolumn{9}{|l|}{ Peach } \\
\hline Multiple & KAC, Fresno & 18 & - & $7-14$ & $\mathrm{~B}$ & 2 & 2 & 2 \\
\hline \multicolumn{9}{|l|}{ Plum } \\
\hline July Santa Rosa & KAC, Fresno & 18 & $7 / 15$ & $7-14$ & $\mathrm{~B}$ & 2 & 2 & 1 \\
\hline Rosemary & Madera, Madera & 10 & $7 / 20$ & 12 & $\mathrm{C}$ & 4 & 2 & 0 \\
\hline \multicolumn{9}{|l|}{$1996-97$} \\
\hline \multicolumn{9}{|l|}{ Nectarine } \\
\hline Fantasia & KAC, Fresno & 22 & $7 / 1$ & $7-14$ & B & 2 & 1 & 1 \\
\hline Summer Red & Parlier, Fresno & 9 & $8 / 15$ & $10-14$ & $\mathrm{C}$ & 2 & 0 & 1 \\
\hline Flaming Red & Madera, Madera & 10 & $8 / 20$ & 12 & $\mathrm{C}$ & 4 & 2 & 1 \\
\hline \multicolumn{9}{|l|}{ Peach } \\
\hline Fairtime & Madera, Madera & _- & $8 / 20$ & 12 & $\mathrm{C}$ & 4 & 2 & 1 \\
\hline \multicolumn{9}{|l|}{ Prune } \\
\hline French & Madera, Madera & - & $9 / 10$ & $10-14$ & B & - & - & - \\
\hline
\end{tabular}

${ }^{\mathrm{w}}$ Number of days between two irrigations throughout the growing season.

${ }^{x}$ Orchard floor management: B denotes herbicides applied only on irrigation berms (tree rows), and C denotes herbicides sprayed on entire orchard floor.

y Number of fungicide applications during periods: $\mathrm{A}=$ bloom, $\mathrm{B}=$ postbloom, and $\mathrm{C}=$ preharvest.

${ }^{\mathrm{z}}$ No data available. 
stone fruits, sampling positions, and sampling months were further analyzed with the SAS CORR procedure.

\section{RESULTS}

Overall, 20 genera represented by 29 species of filamentous fungi and nonfilamentous yeasts were isolated from mummy washings and inner tissues. The principal species recovered were Alternaria alternata, Aspergillus niger, Aspergillus japonicus, Aspergillus orchraceus, Aspergillus terreus, Aureobasidium pullulans, Cladosporium herbarum, Botrytis cinerea, a Fusarium species, Gilbertella persicaria, Mucor racemosus, Penicillium spp., Rhizopus stolonifer, Trichoderma atroviride, and various nonfilamentous yeasts. Minor species included Epicoccum purpurascens, Trichothecium roseum, and species of Geotrichum, Harknessia, Nigrospora, Stemphylium, and Verticillium.

Mycoflora from mummy surface. The fungi most frequently recovered from mummy washings in the 1995-96 winter (Table 2) were species of nonfilamentous yeasts $(32.1 \%)$, Penicillium (28.8\%), Cladosporium (11.4\%), and Mucor (10.8\%). M. fructicola was not recovered from any mummy washings. Similar data were obtained in 1996-97.
Mycoflora from mummy inner tissues. Fungi most frequently recovered from mummy inner tissues in the 1995-96 winter were species of Penicillium (23.7\%), Mucor (19.6\%), Cladosporium (17.3\%), and Rhizopus (11.1\%) (Table 2). In the 1996-97 winter, Penicillium spp. remained the most frequently isolated fungi from inner tissues of mummies sampled, but $M$. fructicola, Aspergillus spp., and nonfilamentous yeasts increased, and species of Botrytis, Cladosporium, and Mucor decreased dramatically from those in 1995-96 (Table 2). Significant differences were observed in the relative recovery of individual fungi among locations, Prunus species, and sampling dates. Differences in the relative recovery also were observed between sampling positions (tree versus ground) and seasons.

Ten genera of fungi had different relative recovery among locations in the 199596 winter, whereas only four genera had different recovery in the 1996-97 winter (Table 3). Lower recoveries of $M$. fructicola were made from mummies collected from the KAC orchards than from those from any other orchards (Table 3 ).

The relative recoveries of Aureobasidium, Fusarium, Gilbertella, Trichoderma, and yeasts did not differ among nectarine, peach, and plum in the 1995-96 winter and among nectarine, peach, and prune in the 1996-97 winter (Table 4); however, higher recoveries of Aspergillus were made from peach mummies than from nectarines (Table 4). Lower recoveries of $M$. fructicola were made from prune mummies than from nectarine and peach mummies in the 199697 winter, although no difference was observed among nectarine, peach, and plum mummies in the 1995-96 winter (Table 4).

The relative recoveries of most fungi were associated consistently with sampling position in both 1995-96 and 1996-97 winters (Table 5). Aureobasidium, Cladosporium, and M. fructicola were isolated more frequently from tree mummies than from ground mummies. In contrast, Mucor, Rhizopus, and yeasts were isolated more frequently from ground mummies than from tree mummies (Table 5). No differences were observed in the relative recoveries of Botrytis and Fusarium between tree and ground mummies (Table 5).

Relative recovery of some colonizing fungi changed consistently throughout the winter (Tables 6 and 7). For example, Penicillium increased, while Aspergillus spp. and M. fructicola decreased as the winter progressed. However, recovery of other species changed dramatically. A con-

Table 3. Relative recovery (\%) of colonizing fungi isolated from inner tissues of stone fruit mummies in California orchards of different locations

\begin{tabular}{|c|c|c|c|c|c|c|c|c|c|}
\hline \multirow[b]{2}{*}{ Fungus } & \multicolumn{5}{|c|}{$1995-96$ winter } & \multicolumn{4}{|c|}{ 1996-97 winter } \\
\hline & Parlier & KAC & Madera & Reedley & $P^{\mathbf{y}}$ & Parlier & KAC & Madera & $P^{y}$ \\
\hline Alternaria & $2.6^{\mathrm{z}}$ & 2.6 & 0.7 & 2.1 & 0.0034 & 0.1 & 0 & 0.7 & 0.2480 \\
\hline Aspergillus & 1.0 & 2.8 & 1.9 & 1.1 & 0.2194 & 7.6 & 13.1 & 7.7 & 0.6949 \\
\hline Aureobasidium & 5.8 & 8.3 & 3.3 & 6.3 & 0.0816 & 0.4 & 1.8 & 1.3 & 0.9523 \\
\hline Botrytis & 5.1 & 15.3 & 5.2 & 2.0 & $<0.0001$ & 0.5 & 3.4 & 1.2 & 0.2667 \\
\hline Cladosporium & 21.4 & 21.7 & 9.7 & 17.1 & 0.0013 & 3.5 & 12.2 & 5.3 & 0.0189 \\
\hline Fusarium & 4.3 & 0.9 & 1.2 & 0.6 & 0.0007 & 0 & 0.3 & 0.9 & 0.2519 \\
\hline Gilbertella & 2.5 & 2.4 & 1.0 & 2.2 & 0.0006 & 0 & 0.1 & 0.2 & 0.2520 \\
\hline Monilinia & 4.4 & 0.7 & 1.2 & 1.3 & 0.0007 & 20.3 & 0.2 & 16.0 & $<0.0001$ \\
\hline Mucor & 17.2 & 7.4 & 20.6 & 37.8 & $<0.0001$ & 4.9 & 5.2 & 6.4 & 0.8999 \\
\hline Penicillium & 15.5 & 27.8 & 34.8 & 9.7 & $<0.0001$ & 39.5 & 40.0 & 27.6 & 0.0075 \\
\hline Rhizopus & 8.5 & 5.2 & 16.7 & 14.7 & $<0.0001$ & 5.7 & 10.6 & 7.9 & 0.8090 \\
\hline Trichoderma & 0.7 & 0.9 & 1.1 & 3.1 & 0.8032 & 2.3 & 1.7 & 4.6 & 0.0974 \\
\hline Yeast & 5.7 & 1.7 & 1.6 & 1.0 & $<0.0001$ & 12.9 & 7.1 & 17.7 & 0.0304 \\
\hline
\end{tabular}

y Significance of Kruskal-Wallis test.

${ }^{\mathrm{z}}$ Relative recovery was calculated by dividing colony number of a genus by total colony number of all fungi.

Table 4. Relative recovery (\%) of colonizing fungi isolated from the inner tissue of different stone fruit mummies in California orchards

\begin{tabular}{|c|c|c|c|c|c|c|c|c|}
\hline \multirow[b]{2}{*}{ Fungus } & \multicolumn{4}{|c|}{ 1995-96 winter } & \multicolumn{4}{|c|}{ 1996-97 winter } \\
\hline & Nectarine & Peach & Plum & $P^{\mathbf{y}}$ & Nectarine & Peach & Prune & $P^{\mathbf{y}}$ \\
\hline Alternaria & $1.8^{\mathrm{z}}$ & 1.6 & 2.3 & 0.2016 & 0.0 & 0.4 & 2.1 & $<0.0001$ \\
\hline Aspergillus & 1.0 & 2.5 & 3.1 & 0.0085 & 9.2 & 13.3 & 0.8 & 0.0255 \\
\hline Aureobasidium & 5.3 & 7.2 & 6.9 & 0.1132 & 0.9 & 2.8 & 0.5 & 0.3485 \\
\hline Botrytis & 7.2 & 17.2 & 5.9 & $<0.0001$ & 1.7 & 1.6 & 0.4 & 0.3917 \\
\hline Cladosporium & 17.9 & 16.8 & 16.5 & 0.8746 & 6.2 & 1.6 & 14.1 & 0.0025 \\
\hline Fusarium & 1.6 & 0.7 & 1.3 & 0.7350 & 0.6 & 0.5 & 0.6 & 0.8089 \\
\hline Gilbertella & 0.7 & 1.8 & 3.9 & 0.6891 & 0.1 & 0 & 0.6 & 0.1123 \\
\hline Monilinia & 2.0 & 0.9 & 1.0 & 0.1806 & 17.2 & 11.6 & 0.2 & $<0.0001$ \\
\hline Mucor & 21.8 & 6.9 & 20.7 & 0.0025 & 5.1 & 5.9 & 8.9 & 0.2621 \\
\hline Penicillium & 21.4 & 33.2 & 23.8 & 0.0001 & 33.3 & 30.9 & 33.3 & 0.8610 \\
\hline Rhizopus & 13.1 & 4.3 & 10.4 & 0.0149 & 6.6 & 13.4 & 6.7 & 0.0162 \\
\hline Trichoderma & 1.5 & 0.4 & 1.7 & 0.7595 & 2.5 & 4.7 & 5.9 & 0.2304 \\
\hline Yeast & 2.3 & 2.4 & 1.6 & 0.6663 & 14.0 & 11.4 & 20.3 & 0.4761 \\
\hline
\end{tabular}

y Significance of Kruskal-Wallis test.

${ }^{\mathrm{z}}$ Relative recovery was calculated by dividing colony number of individual fungi by total of colonies of all fungi. 
sistent decrease of Cladosporium and an increase of Mucor were observed in 199596 (Table 6), but these trends were not observed in 1996-97 (Table 7). The relative recovery of Fusarium, Rhizopus, Trichoderma, and other fungi and nonfilamentous yeasts were low and showed no consistent seasonal pattern (Tables 6 and 7).

The correlation coefficients between $M$. fructicola and the principal colonizing fungi were species of Alternaria $0.71(P=$ 0.0043), Aureobasidium $0.75(P=0.0021)$, Botrytis $-0.53(P=0.052)$, Penicillium $0.58(P=0.0681)$, Rhizopus $-0.50(P=$ $0.0696)$, and nonfilamentous yeasts $0.87(P$ $<0.0001$ ), respectively (Table 8).

\section{DISCUSSION}

This study is the first attempt to determine the mycoflora of the surface and inner tissues of the carpo-stromasphere using Prunus mummies. The mycofloral communities of stone fruit mummies are more complex than those reported for peach twigs (22,24). Among 29 species recovered, A. japonicus, A. terreus, and species of Harknesia, Paecilomyces, and T. atroviride were first recorded on Prunus crops in the United States, and A. pullulans, and E. purpurascens had not been

Table 5. Relative recovery (\%) of colonizing fungi isolated from inner tissues of stone fruit mummies collected from trees and the ground in California orchards

\begin{tabular}{|c|c|c|c|c|c|c|}
\hline \multirow[b]{2}{*}{ Fungus } & \multicolumn{3}{|c|}{ 1995-96 winter } & \multicolumn{3}{|c|}{ 1996-97 winter } \\
\hline & Tree & Ground & $P^{y}$ & Tree & Ground & $P^{\mathrm{y}}$ \\
\hline Alternaria & $2.9^{\mathrm{z}}$ & 1.1 & $<0.0001$ & 0.7 & 0.2 & 0.6336 \\
\hline Aspergillus & 1.9 & 2.0 & 0.5066 & 13.3 & 4.5 & 0.0125 \\
\hline Aureobasidium & 9.4 & 3.1 & $<0.0001$ & 1.9 & 0.6 & 0.0407 \\
\hline Botrytis & 8.4 & 7.6 & 0.4254 & 1.3 & 1.8 & 0.4887 \\
\hline Cladosporium & 29.0 & 6.6 & $<0.0001$ & 11.2 & 1.8 & $<0.0001$ \\
\hline Fusarium & 0.8 & 1.9 & 0.2135 & 0.1 & 1.0 & 0.1647 \\
\hline Gilbertella & 1.0 & 2.8 & $<0.0001$ & 0.1 & 0.2 & 0.3367 \\
\hline Monilinia & 2.4 & 0.6 & 0.0003 & 21.7 & 5.7 & $<0.0001$ \\
\hline Mucor & 5.1 & 32.9 & $<0.0001$ & 0.6 & 10.8 & $<0.0001$ \\
\hline Penicillium & 28.5 & 19.4 & 0.0023 & 33.1 & 32.4 & 0.7553 \\
\hline Rhizopus & 6.2 & 15.5 & $<0.0001$ & 4.6 & 11.2 & 0.0039 \\
\hline Trichoderma & 1.3 & 1.5 & 0.3347 & 0.6 & 6.3 & $<0.0001$ \\
\hline Yeast & 1.6 & 2.5 & 0.0460 & 8.0 & 20.6 & $<0.0001$ \\
\hline
\end{tabular}

${ }^{y}$ Significance of Kruskal-Wallis test.

${ }^{\mathrm{z}}$ Relative recovery was calculated by dividing colony number of individual fungi by total colony number of all fungi.

Table 6. Seasonal populations of colonizing fungi isolated from inner tissues of stone fruit mummies in California orchards, 1995-96 winter

\begin{tabular}{|c|c|c|c|c|c|c|}
\hline \multirow[b]{2}{*}{ Fungus } & \multicolumn{5}{|c|}{ Relative recovery $(\%)^{\mathrm{y}}$} & \multirow[b]{2}{*}{$P^{z}$} \\
\hline & Nov. & Dec. & Jan. & Feb. & Mar. & \\
\hline Alternaria & 5.9 & 6.5 & 1.0 & 2.7 & 0.1 & $<0.0001$ \\
\hline Aspergillus & 7.8 & 2.0 & 1.1 & 2.5 & 0.3 & 0.0178 \\
\hline Aureobasidium & 10.9 & 15.6 & 9.6 & 4.9 & 1.7 & $<0.0001$ \\
\hline Botrytis & 0 & 0 & 7.7 & 8.6 & 10.4 & 0.1808 \\
\hline Cladosporium & 51.8 & 34.4 & 22.4 & 11.1 & 10.7 & $<0.0001$ \\
\hline Fusarium & 0 & 1.3 & 0.1 & 2.9 & 0 & $<0.0001$ \\
\hline Gilbertella & 8.2 & 0.9 & 0.3 & 1.7 & 4.9 & 0.0009 \\
\hline Monilinia & 4.6 & 14.1 & 2.1 & 0 & 0 & $<0.0001$ \\
\hline Mucor & 1.8 & 11.1 & 17.9 & 21.1 & 25.7 & 0.0866 \\
\hline Penicillium & 1.8 & 3.0 & 24.7 & 21.2 & 38.8 & 0.0004 \\
\hline Rhizopus & 5.4 & 1.7 & 8.6 & 15.1 & 7.7 & $<0.0001$ \\
\hline Trichoderma & 0.3 & 0 & 1.1 & 2.4 & 0 & 0.0106 \\
\hline Yeast & 0 & 9.7 & 1.2 & 3.2 & 0 & $<0.0001$ \\
\hline
\end{tabular}

y Relative recovery was calculated by dividing colony number of individual fungi by total colony number of all fungi.

${ }^{\mathrm{z}}$ Significance of Friedman's test.

Table 7. Seasonal populations of colonizing fungi isolated from the inner tissues of stone fruit mummies in California orchards, 1996-97 winter

\begin{tabular}{|c|c|c|c|c|c|c|}
\hline \multirow[b]{2}{*}{ Fungus } & \multicolumn{5}{|c|}{ Relative recovery $(\%)^{y}$} & \multirow[b]{2}{*}{$P^{z}$} \\
\hline & Nov. & Dec. & Jan. & Feb. & Mar. & \\
\hline Alternaria & 0 & 0.1 & 0.5 & 0.8 & 0.7 & 0.7334 \\
\hline Aspergillus & 35.9 & 6.3 & 0.1 & 2.1 & 4.6 & $<0.0001$ \\
\hline Aureobasidium & 1.6 & 2.81 & 0.4 & 1.3 & 0 & 0.0704 \\
\hline Botrytis & 0.1 & 3.8 & 2.2 & 0.8 & 0.3 & 0.0103 \\
\hline Cladosporium & 4.1 & 8.1 & 5.6 & 5.6 & 7.9 & 0.5564 \\
\hline Fusarium & 0 & 0 & 0.9 & 0 & 2.0 & 0.0142 \\
\hline Gilbertella & 0 & 0.3 & 0 & 0.4 & 0 & 0.3839 \\
\hline Monilinia & 22.0 & 18.0 & 8.3 & 12.8 & 7.7 & 0.0225 \\
\hline Mucor & 7.0 & 4.1 & 5.5 & 4.1 & 9.1 & 0.2654 \\
\hline Penicillium & 8.1 & 15.4 & 44.5 & 43.9 & 48.6 & $<0.0001$ \\
\hline Rhizopus & 4.4 & 9.6 & 6.7 & 6.3 & 12.8 & 0.1240 \\
\hline Trichoderma & 0 & 2.1 & 5.9 & 5.2 & 3.7 & 0.0396 \\
\hline Yeast & 15.7 & 27.3 & 15.6 & 11.9 & 0.4 & $<0.0001$ \\
\hline
\end{tabular}

y Relative recovery was calculated by dividing colony number of individual fungi by total colony number of all fungi.

${ }^{\mathrm{z}}$ Significance of Friedman's test. 
reported in California before (10). This study provides initial ecological data on the colonization of the carpo-stromasphere, which may help in understanding the survival of $M$. fructicola overwintering in California stone fruit orchards.

Most colonizing fungi such as Penicillium spp. were present consistently on mummy surfaces and inner tissues throughout both winters. Lower recoveries of M. fructicola were associated with higher recoveries of species of Botrytis, Penicillium, Mucor, Rhizopus, and Trichoderma. M. fructicola was not recovered from mummies, which were overgrown with species of $B$. cinerea, $C$. herbarum, $M$. racemosus, Penicillium spp., $R$. stolonifer, $T$. atroviride, or by $T$. roseum in commercial orchards. Some of these commonly recovered fungi may have contributed to the decline in the recovery of $M$. fructicola from mummies during the winter, and thus contributed to the reduction of primary inoculum in California orchards. The mechanisms by which these fungi suppress $M$. fructicola might be through substrate competition and niche exclusion (23), antibiosis (2), or both. An in vitro antagonism study indicated that these commonly isolated fungi and yeasts reduced the mycelial growth of $M$. fructicola on APDA dishes, even when the pathogen was seeded 2 days earlier than the colonizing fungi (data not shown). It must be noted that both $B$. cinerea and $R$. stolonifer are weak pathogens of stone fruits of early season varieties, and of minor importance when compared with brown rot in California. It may be possible to promote naturally occurring colonizing fungi by modifying cultural practices to favor biological control of brown rot, particularly in orchards of late-season varieties. The best strategies and methods for maximal use of these naturally occurring colonizer antagonists for control of brown rot need further investigation.
An antagonist sought for use in soil, on a plant surface, or within a plant tissue is most likely to develop in that niche if it was originally obtained from a similar niche (4). For example, E. purpurascens and $A$. pullulans were isolated from blossoms and developed as control agents of brown rot blossom blight and latent infection of cherry by $M$. fructicola in the United States (30). P. frequentans and E. purpurascens were obtained from peach twigs and were shown to be effective for controlling infections of blossoms and twigs by Monilinia laxa in Spain $(6,20)$. A wide range of antagonists such as A. pullulans, E. purpurascens $(20,21)$, Trichoderma spp. $(7,8,11,16)$, and $T$. roseum (4) were obtained in the present study. These fungi have potential and warrant further investigation for the reduction of primary inoculum and brown rot blossom blight in stone fruits.

Similar mycoflora were associated with peach, nectarine, plum, and prune mummies. Variations in relative recovery of some filamentous fungi and nonfilamentous yeasts between the two winters were expected because of different weather conditions. It was very dry and warm in the second half of 1995, but it was much wetter and cooler in the same period of 1996. The relative recovery of some filamentous fungi and nonfilamentous yeasts from mummies at the KAC orchards differed from those in other orchards. The trees sampled at the KAC orchards were about 10 years older, and fruit harvest date was 1.5 months earlier than for those in the other orchards. The association of mycoflora in stone fruit mummies with tree age and fruit harvest date has not been studied. The application of fungicides may affect the recovery of $M$. fructicola (27) and some other species, but the orchards we sampled in this research received similar fungicide sprays. The higher recoveries of Mucor and Rhizopus spp. from the ground mummies than from tree mummies can be explained by the common occurrence of these fungi in soil (7).

\section{ACKNOWLEDGMENTS}

This research was supported in part by a grant from the University of California Statewide Integrated Pest Management Project, California State Department of Pesticide Regulation (Sacramento), the California Tree Fruit Agreement (Reedley), and the California Prune Board (Pleasanton). We thank growers for providing details of irrigation and pesticide applications in their orchards. Our thanks extend to M. A. Doster for assisting with the identification of Aspergillus isolates, O. Schabenberger for the advice on data analyses, and $\mathrm{B}$ $\mathrm{L}$. Teviotdale for critically reviewing the manuscript.

\section{LITERATURE CITED}

1. Biggs, A. R., and Northover, J. 1985. Inoculum sources for Monilinia fructicola in Ontario peach orchards. Can. J. Plant Pathol. 7:302-307.

2. Blakeman, J. P., and Fokkema, N. J. 1982 Potential for biological control of plant diseases on the phylloplane. Annu. Rev. Phytopathol. 20:167-192.

3. Byrde, R. J. W., and Willetts, H. J. 1977. The Brown Rot Fungi of Stone Fruit: Their Biology and Control. Pergamon Press, Oxford.

4. Cook, R. J., and Baker, K. F. 1983. The Nature and Practice of Biological Control of Plant Pathogens. American Phytopathological Society, St. Paul, MN.

5. De Cal, A., and Melgarejo, P. 1992. Interaction of pesticides and mycoflora of peach twigs. Mycol. Res. 96:1105-1113.

6. De Cal, A., M-Sagasta, E., and Melgarejo, P. 1990. Biological control of peach twig blight (Monilinia laxa) with Penicillium frequentans. Plant Pathol. 39:612-618.

7. Domsch, K. L., Gams, W., and Anderson, T. H. 1980. Compendium of Soil Fungi. Vol. I. Academic Press, New York.

8. Elad, Y., Chet, I., and Katan, J. 1980. Trichoderma harzianum: A biocontrol agent effective against Sclerotium rolfsii and Rhizoctonia solani. Phytopathology 70:119-121.

9. Falconi, C. J., and Mendgen, K. 1994. Epiphytic fungi on apple leaves and their value for control of the postharvest pathogens $\mathrm{Bo}$ trytis cinerea, Monilinia fructigena and Penicillium expansum. J. Plant Dis. Prot. 101:3847.

Table 8. Correlation analysis of colonizing fungi isolated from inner tissues of stone fruit mummies infected by Monilinia fructicola in California orchards ${ }^{\mathrm{x}}$

\begin{tabular}{|c|c|c|c|c|c|c|c|c|c|c|c|c|c|c|}
\hline \multirow[b]{2}{*}{ Fungus } & \multicolumn{14}{|c|}{ Pearson correlation coefficient (upper right) $/ P>|R|\left(\right.$ lower left) ${ }^{y}$} \\
\hline & Alt & Asp & Aur & Bot & Cla & Fus & Gil & Mon & Muc & Pen & Rhi & Tri & Yea & Oth \\
\hline Alternaria ${ }^{\mathrm{z}}$ & & 0.62 & 0.81 & -0.56 & 0.83 & 0.02 & 0.29 & 0.71 & -0.54 & -0.79 & -0.54 & -0.25 & 0.51 & -0.16 \\
\hline Aspergillus & 0170 & & 0.37 & -0.26 & 0.70 & -0.24 & 0.69 & 0.00 & -0.55 & -0.45 & -0.26 & -0.21 & -0.21 & -0.02 \\
\hline Aureobasidium & 0004 & 1874 & & -0.35 & 0.82 & -0.25 & -0.05 & 0.75 & -0.62 & -0.58 & -0.72 & -0.32 & 0.48 & -0.18 \\
\hline Botrytis & 0380 & 3769 & 2191 & & -0.46 & -0.06 & -0.23 & -0.53 & 0.18 & 0.76 & -0.13 & -0.11 & -0.28 & 0.41 \\
\hline Cladosporium & 0002 & 0057 & 0005 & 0957 & & -0.28 & 0.43 & 0.49 & -0.70 & -0.64 & -0.65 & -0.41 & 0.13 & -0.11 \\
\hline Fusarium & 9334 & 4130 & 3794 & 8375 & 3257 & & -0.25 & 0.13 & 0.17 & -0.15 & 0.30 & 0.19 & 0.53 & 0.64 \\
\hline Gilbertella & 3169 & 0054 & 8668 & 4308 & 1270 & 3846 & & -0.21 & -0.16 & -0.26 & -0.18 & -0.29 & -0.40 & -0.13 \\
\hline Monilinia & 0043 & 9992 & 0021 & 0502 & 0787 & 6524 & 4635 & & -0.27 & -0.58 & -0.50 & -0.39 & 0.87 & -0.23 \\
\hline Mucor & 0457 & 0401 & 0189 & 5430 & 0056 & 5655 & 5915 & 3419 & & 0.04 & 0.76 & 0.61 & -0.12 & -0.17 \\
\hline Penicillium & 0008 & 1042 & 0287 & 0014 & 0146 & 6037 & 3642 & 0681 & 8995 & & 0.14 & -0.09 & -0.44 & 0.05 \\
\hline Rhizopus & 0481 & 3727 & 0034 & 6461 & 0114 & 3050 & 5400 & 0696 & 0016 & 6271 & & 0.73 & -0.30 & 0.00 \\
\hline Trichoderma & 3835 & 4773 & 2573 & 7074 & 1502 & 5075 & 3088 & 1688 & 0201 & 7636 & 0032 & & -0.24 & 0.11 \\
\hline Yeast & 0610 & 4774 & 0856 & 3235 & 6500 & 0512 & 1509 & 0001 & 6827 & 1150 & 2909 & 4084 & & 0.01 \\
\hline Others & 5889 & 9397 & 5343 & 1474 & 7059 & 0143 & 6522 & 4319 & 5560 & 8558 & 9998 & 9062 & 7093 & \\
\hline
\end{tabular}

${ }^{\mathrm{x}}$ Data of colonizer fungi analyzed were the means of relative recovery of each of four locations, three Prunus spp., two sampling positions (tree versus ground), and 5 months, so that $\mathrm{N}=14$.

y Pearson correlation coefficients are listed in the upper right corner, and statistical significance is presented in the lower left corner of the table.

${ }^{\mathrm{z}}$ Bold letters indicate abbreviation of each genus used in horizontal subtitle of table. 
10. Farr, D. F., Bills, G. F., Chamuris, G. P., and Rossman, A. Y. 1989. Fungi on Plants and Plant Products in the United States. American Phytopathological Society, St. Paul, MN.

11. Fernandez, M. R. 1992. The effect of Trichoderma harzianum on fungal pathogens in infesting soybean residues. Soil Biol. Biochem. 24:1027-1029.

12. Holtz, B. A., Michailides, T. J., and Hong, C. X. 1998. Development of apothecia from stone fruit infected and stromatized by Monilinia fructicola in California. Plant Dis. 82:1375-1380

13. Hong, C. X., Michailides, T. J., and Holtz, B. A. 1996. Survival of Monilinia fructicola in mummified fruits in San Joaquin Valley of California. (Abstr.) Phytopathology $86: \mathrm{S} 4$.

14. Hong, C. X., Michailides, T. J., and Holtz, B. A. 1996. Resident fungi of stone fruits mummified by Monilinia fructicola. (Abstr.) Phytopathology 86:S81.

15. Hong, C. X., Michailides, T. J., and Holtz, B. A. 1996. Survey of primary inoculum sources of brown rot in stone fruit orchards in the San Joaquin Valley of California. (Abstr.) Phytopathology 86:S110.

16. Hong, C. X., Michailides, T. J., and Holtz, B. A. 1998. Effects of wounding, inoculum density, and biological control agents on posthar- vest brown rot of stone fruits. Plant Dis. $82: 1210-1216$

17. Hornby, D. 1983. Suppressive soils. Annu. Rev. Phytopathol. 21:65-85.

18. Landgraf, F. A., and Zehr, E. I. 1982. Inoculum sources for Monilinia fructicola in South Carolina peach orchards. Phytopathology 72:185-190.

19. Leben, C. 1965. Epiphytic microorganisms in relation to plant disease. Annu. Rev. Phytopathol. 3:209-230.

20. Madrigal, C., Tadeo, J. L., and Melgarejo, P. 1991. Relationship between flavipin production by Epicoccum nigrum and antagonism against Monilinia laxa. Mycol. Res. 95:13751381.

21. Mallea, M., Pesando, D., Bernard, P., and Khoulalene, B. 1991. Comparison between antifungal and antibacterial activities of several strains of Epicoccum purpurascens from the Mediterranean area. Mycopathologia 115:83-88.

22. Melgarejo, P., Carrillo, R., and M-Sagasta, E. 1985. Mycoflora of peach twigs and flowers and its possible significance in biological control of Monilinia laxa. Trans. Br. Mycol. Soc. 85:313-317.

23. Ogawa, J. M., and English, H. W. 1991. Diseases of Temperate Zone Tree Fruit and Nut Crops. Publ. 3345. University of California,
Division of Agriculture and Natural Resources, Oakland.

24. Royse, D. J., and Ries, S. M. 1978. The influence of fungi from peach twigs on the pathogenicity of Cytospora cincta. Phytopathology 68:603-607.

25. Schippers, B., Bakker, A. W., and Bakker, P. A. H. M. 1987. Interactions of deleterious and beneficial rhizosphere microorganisms and the effect of cropping practices. Annu. Rev. Phytopathol. 25:339-358.

26. Weller, D. M. 1988. Biological control of soilborne plant pathogens in the rhizosphere with bacteria. Annu. Rev. Phytopathol. 26:379-407.

27. Wilcox, W. F. 1990. Postinfection and antisporulant activities of selected fungicides in control of blossom blight of sour cherry caused by Monilinia fructicola. Plant Dis. 74:808-811.

28. Wilson, C. L. 1989. Managing the microflora of harvested fruits and vegetables to enhance resistance. Phytopathology 79:1387-1390.

29. Wilson, D. 1995. Endophyte - the evolution of a term, and classification of its use and definition. Oikos 73:274-276.

30. Wittig, H. P. P., Johnson, K. B., and Pscheidt, J. W. 1997. Effect of epiphytic fungi on brown rot blossom blight and latent infections in sweet cherry. Plant Dis. 81:383-387. 